\title{
INNOVATION MANAGEMENT STUDIES: TECHNOLOGICAL ADVANCE AND CHALLENGES OF GLOBALIZATION
}

\author{
Borisas Melnikas \\ Department of International Economics and Business Management, \\ Vilnius Gediminas Technical University, \\ Sauletekio al. 11, LT-10223 Vilnius, Lithuania \\ E-mail: borisas.melnikas@vgtu.lt
}

\begin{abstract}
The essence, principles, the needs and opportunities of the improvement of the innovation management studies, as well as main priorities and trends of the innovation management specialists education and training systems development are investigated and discussed. Main problems and improvement priorities in the field of innovation management studies, particularly - under contemporary conditions of globalization and in the context of the needs of technological advance, are identified and analyzed. A complex analysis of current situation and of the development of innovation management studies and of innovation management specialists education and training systems modernization processes and problems is presented. Special attention is paid to innovation management specialists education, training and development under contemporary conditions and challenges of globalization, knowledge based society creation, European integration and the European Union's enlargement, as well as to the needs of the improvement of innovation management studies in accordance with the processes and priorities of the high technology sectors development and activation of the technological advance in general.

The absence of well-founded general and special principles of innovation management studies and innovation management specialists education, training and development, as well as the absence of special principles of innovation management studies under contemporary conditions of globalization and in the context of the needs of technological advance could be defined as an especially important scientific, practical and research problem.

An in-depth analysis of innovation management specialists' development principles and practical experiences in the area of innovation management specialists education and training is provided.
\end{abstract}

Keywords: innovation, technological advance, management, globalization, education, training, study.

JEL Classification: A10; F01; F39; O39; Q39.

\section{Introduction}

Innovation activities and technological advance in all spheres of social and economic life, as well as creation of knowledge based society and knowledge economy in general could be defined as an especially important priority of the development processes and changes in the society, its life and culture under contemporary conditions of globalization. It is obvious that there are many needs to improve innovation management, also potential of human resources in the field of innovation managemet, as well as innovation management studies, training and education.

Improvement of innovation management studies, as well as innovation management training and education systems in general should be defined as an especially important precondition to activate innovations and technological advance in accordance with contemporary needs and challenges.
Innovation management studies and the systems of innovation management training and education in general should be defined as specific field of scientific cognition and research. Naturally, the lack of theoretical knowledge and deficiency of positive practical experiences of effective innovation management in various spheres of social and economic life and technological progress could be defined as an important scientific problem: the importance of this problem leads to the need for scientific research on purposeful improvement of innovation management studies in accordance with contemporary orientations to the technological advance under conditions of globalization and knowledge based society creation.

Topicality of this scientific problem is conditioned by the necessity to perceive innovation management studies and, in general, innovation management specialists development as a system, 
further development of which could have a direct and positive impact on social, economic and technological progress adequate to possibilities provided by globalization, development of international cooperation and dissemination of ideas of the creation of knowledge based society. Furthermore, the modern world is witnessing a rapid formation of multicultural spaces, where priority is given to activities in global economy and international cooperation, and very intensive processes of increasing expansion of information and other modern technologies that lead to high concentration of intellectual work and innovation activities: innovation management specialists development systems must have the capacity to react to this situation and to manage those global processes.

Complexity of this scientific problem is predetermined by the fact that recognition of a problem and search for possible solutions requires integration of many scientific fields and trends, as well as synthesis of theoretical suppositions and practical actions and decisions: enhancement of innovation management specialists development requires a complex scientific research and new theoretical approach, as well as tests of various theoretical models.

Many aspects of this scientific problem are discussed in previous author's works and publications (Melnikas 2002, 2010, 2011, 2013, 2014): it could be noted that there are many additional needs for scintific research on the further improvement and modernization of innovation management studies and, in general, innovation management specialists development systems.

Aim of the research - to reveal the problem areas related to modern innovation management studies and, in general, innovation management specialists development, as well as to prepare a theoretical concept which would be used purposefully to improve and develop innovation management studies in accordance with contemporary orientations to the technological advance under conditions of globalization and knowledge based society creation.

Main tasks of the research - to define the role and functions of innovation management specialists in contemporary society and to highlight the key priorities of modern innovation management studies, to define main principles of modern innovation management studies, as well as of improvement of these studies, to highlight the strengthening of the potential of innovation managers creativity as a key priority of the improvement of the innovation management studies, training and education systems in general.
Methodology of the research - logical and comparative analysis of various theoretical approaches and concepts.

\section{Innovation management studies and innovation management specialists development systems: essence, problems and improvement priorities}

Contemporary society and its development can be characterized by some complex phenomena, embodying various challenges, new values and further development priorities. It can be stated that the role of innovation management in contemporary society is growing rapidly; its quality and efficiency, innovation management specialists' qualification, competence and capacity are becoming crucial factors of the modern society development. Of course, the role of innovation management studies as well as the role of innovation management specialists development systems in general is also growing rapidly, innovation management studies and the systems of innovation management specialists development gets exceptional significance. Seeking to form a modern society, priority should be given to innovation management specialist development and enhancement of innovation management specialist development systems (Armstrong 1999; Grace, Butler 2005; Huseman, Godman 1999; Leydesdorff 2004; Steinmueller 2002; Melnikas 2002, 2010, 2011, 2013, 2014).

It is necessary to extend and deepen the approach to innovation management studies and to the systems of innovation management specialists development, especially according to the present challenges of globalization and activation of thechnological advance (Melnikas 2014).

Definitions of innovation management studies and of the systems of innovation management specialists development could be described in various ways. The following definitions could be characterized as the universal:

- innovation management studies - studies, which are focused on the acquisition of theoretical and practical knowledge in innovation activities and innovation management, as well as on the various skills and abilities in the initiation, creation, dissemination and use of innovations, in management and administration of innovation activities: these studies should combine different forms of teaching, learning, research and practical activities (it can emphasize the importance of university studies in innovation management);

- the systems of innovation management specialists development - the systems, which unites 
and combines a various education, training, research, as well as practical activities in the initiation, creation, dissemination and use of innovations, in management and administration of innovations, various activities of life long learning: these systems could be defined as an organized environment in which various managers, specialists and professionals can continuously improve and develop in the fields of innovation management and innovation activities.

It could be noted that innovation management studies, especially university studies in innovation management, could be defined as an exceptionally important part of many systems of innovation management specialists development: innovation management study processes should be defined as a key element in the processes of the innovation management specialists development in general.

The suggested definition implies a few important aspects of the innovation management specialists development system:

- this system is totality of institutions and organizations working together in the same direction and in cooperation with each other, this system is dynamic because the institutions and organizations involved are currently operating and their operation is directed and coordinated (directed and coordinated operation enables the system to fulfil functions of management and self-regulation);

- institutions and organizations which are part of this system are united by one common goal - to develop and further enhance the potential of properly qualified management specialists, especially - innovation management specialists;

- this system is oriented to encourage specialists' ability, on the one hand, to adjust to the environment (innovation management specialists are developed relevantly to the needs) and, on the other hand, to have a purposeful and active impact on the environment (innovation management specialists are developed with a view to possible future needs and they have to be able to take active part in changing economic, social and technological situations, encouraging scientific and technological progress; they also have to be innovative, creative and competitive: all these qualities show orientation to the continuity of the development);

- this system is oriented to both training individuals and modernization of the society, the priority being development of high quality human resources under conditions of globalization and knowledge based society and knowledge economy creation

The importance of innovation management specialists development systems enhancement in present situation is determined by a few important conditions:

- innovation management specialists' decisions and their performance have an increasing role in choosing new perspective directions and priorities for science and technology development;

- innovation management specialists tend to become a link between people and their society on the one hand and various technical and other systems on the other hand: management specialists' decisions and their actions have a growing impact on interaction between people and their society and biological, technical, technological, informational and other environments, and also significantly affect our possibilities to use modern means of automatization, robotization, computerization, introduction of information and other technologies;

- innovation management specialists' performance becomes a crucial factor in globalization and internationalization of economic, social, cultural, informational, scientific and technological progress and development.

It is also noteworthy that elements of the synergetic effects search, of integration and synthesis are inherent to the innovation management specialists' professional activities (Melnikas 2011, 2013): these elements have various expressions ( an important characteristic of innovation managerial activity is the combination of different activities which requires knowledge, skills and experience of different kind and character). Elements of the synergetic effects search, of integration and synthesis, inherent to innovation management specialists' performance, show that innovation management specialists fulfil the functions of synergetic effects formation: these functions could be defined as especially important under conditions of the knowledge based society and knowledge economy creation and in the context of contemporary processes of technological advance (Currie 2000; David, Foray 2002; Goeransson, Soederberg 2005; Hunt 2000; Olsen, Osmundsen 2003; Melnikas 1999, 2002, 2011, 2013, 2014).

Awareness of the importance of innovation management specialist development determines the necessity to identify the main problems arising in this field and to outline specific ways to design and enhance efficient innovation management specialist development systems.

In general, innovation management specialist development is a highly extensive and complicated sphere and therefore the typical problems inherent to this sphere can be addressed and analyzed from different aspects. There are many specific characteristics of innovation management specialist de- 
velopment in various situations, under conditions of different social, economic, cultural and technological environment, as well as in variuos countries and under various conditions in different business or public sectors. In-depth analysis of innovation management specialist development practice shows that the following groups of problems can be distinguished:

- problems related to the content of innovation management specialist development;

- problems related to innovation management specialists development technologies and organizational forms;

- problems related to the operation of institutions, enterprises and organizations involved in processes of the innovation management specialist development.

All these problems are analyzed in detail in previous author's publications (Melnikas 2010, $2011,2013)$. Manifold problems arising in innovation management specialist development may be resolved in various ways. That is why some priorities in dealing with the problems have to be highlighted.

Taking in view many specific features of innovation management specialist development and various possibilities to enhance the whole complex of development processes, it could be noted that the main priorities in dealing with management specialist development problems include:

- establishment of principles for innovation management specialist development enhancement on the basis of systematic approach, and preparation and implementation of relevant means for realization of these principles;

- development of infrastructure of interaction between systems of education and training (educational systems) and systems of professional activities of innovation managers (professional systems);

- development of specialists' creativity and innovative potential.

The above mentioned priorities include manifold possibilities that have to be used for the purpose of innovation management specialist development improvement (Boldrin, Canova 2001; Hofbauer 2003; Melnikas 2002, 2011, 2013, 2014).

\section{Improvement of innovation management studies and innovation management specialists development systems: main principles}

Seeking to improve innovation management specialist development, systematic approach has to be adopted, which would refer to all developmental processes as to one system: that means that innova- tion management studies and, in general, innovation management specialists development has to be perceived as a systematic phenomenon and, consequently, the measures applied have to be of systematic character.

A systematical approach is a compulsory condition for dealing with various questions that arise in the process of innovation management specialist development systems development. Furthermore, the systematical approach has to be based on certain principles: these principles highlight the most important requirements for innovation management specialists development and outline priorities for innovation management studies and innovation management specialists development enhancement (Melnikas 2010).

Priciples which could be used for the innovation management specialists development systems improvement and enhancement may include very wide areas. Hence, they may be classified into the following groups:

- general principles of development of modern specialists, which are applicable to development of all specialists, including innovation management specialists;

- specific principles of innovation management specialist development, which embody specific features of innovation management specialist development;

- principles of development of innovation management specialists of different areas, which embody peculiarities of those areas, including the area of business and public innovation management.

A very important condition for successful development and enhancement of innovation management specialists development systems is the ability to take these principles into consideration and to act accordingly.

The universal principles of the specialist development are those which are applicable to the establishment, development and enhancement of development systems for specialists of all areas. These principles are considered to be universal and have to be treated as priorities when dealing with essential issues of establishment and enhancement of various specialists development systems (Armstrong 1999; Grace, Butler 2005). These principles and various aspects of their implementation are described in detail in previous author's publications (Melnikas 2010, 2011, 2013).

Specific principles of innovation management specialists development include:

- the principle of wide erudition and a complex approach to formation of knowledge and 
skills, which means that innovation management specialists development system has to be oriented to the development of wide erudition and widerange knowledge and skills of various fields of life and at the formation of various skills and abilities for different fields of activity;

- the principle of balancing general managerial competence against skills for a specific innovation management field, which means that innovation management specialists have to master both management knowledge and skills of general character and those inherent to a specific field of innovation management (as to specific management skills, priority is given to knowledge of and skills in special - technological, social, economic, law fields relevant to their specialization);

- the principle of innovativeness and creativity, which means that innovation management specialists development system has to be oriented to promoting and developing innovative and creative potential

- the principle of priority of morality and higher social responsibility, which means that innovation management specialists development system seeks to implement high standards of morality and social responsibility;

- the principle of independent decisionmaking, ability to react instantly to rapidly changing situation and take appropriate measures in extreme situations, which means that innovation management specialists development system has to be oriented to the development of independent and responsible leaders;

- the principle of development of team-work skills, tolerance and adaptability, which means that innovation management specialists development system has to aim at development of skills necessary for work in fast-changing environment of people and professionals and for taking active and constructive part in idea generation and decision making (this principle, by the way, is also directly linked to the provision to develop leaders able to work in teams and at the same time remain independent);

- the principle of adaptation to multicultural environment, which means that innovation management professionals have to be able to adapt to any new cultural environment and to carry out their functions successfully;

The above mentioned specific principles not only express specific features of innovation management specialists development, but also outline additional requirements for innovation management specialists development systems. It is noteworthy that such requirements are also predeter- mined by the factors which express specific features inherent to innovation management of various fields, including those of business management and public innovation management. Peculiarities of business innovation management and public innovation management, which are two separate fields of innovation management, require to define additionally the specific principles of innovation management specialists development which are inherent to both business innovation management and public innovation management: awareness of these principles facilitates development and enhancement of innovation management specialists development systems.

Specific nature of business innovation management determines requirements for business innovation management specialists development and, at the same time, specific principles of business innovation management specialist development. These principles include:

- the principle of economic pragmatism priorities, which means that business innovation management specialists have to develop their orientation to economic results;

- the principle of entrepreneurship skills, priority given to abilities to expand business in the environment of democracy, humanism, openness, rule of law and civil society: business innovation management specialists development has to be oriented to business development under conditions of modern democratic, moral and humane society,

- the principle of scientific and technological progress, seek for high quality and productivity, which means that orientation to scientific and technological progress, high quality and productivity are priorities of business innovation management specialist development.

Similar to business innovation management specialists development, public innovation management specialist development systems are guided by both universal and specific principles, applicable to the development of all management and innovation management specialists; additionally, it is guided by principles specific only to public innovation management specialists development.

Specific features of public management and public innovation management determine requirements for public innovation management specialists development and specific principles of public innovation management specialists development. The main principles of this kind are as follows:

- the principle of relevant identification and evaluation of the public and state interests which means that publicinnovation management specialist development has to be oriented to development 
of skills necessary to identify and evaluate the public and state interests and then act in their interest; it also implies that the public and state interests are of top priority;

- the principle of morality, justice and lawfulness, which means that priority has to be given to the development of the ability to remain moral, just and law-abiding in any situation;

- the principle of tolerance and ability to act adequately in multicultural environments and environments of diverse opinions and interests, which means that the ability to remain tolerant to other cultures, mentalities, opinions and interests in any situation is a fundamental priority.

Implementation of these principles is a prerequisite for formation of public innovation management specialists development systems which are relevant to the contemporary needs and challenges.

\section{The strengthening of the potential of innovation managers creativity as a key priority of the improvement of the innovation management studies}

An essential condition for ensuring high quality innovation management is improvement of specialists development systems and their further modernization in view of the fast-changing needs and challenges: this condition gains crucial importance in all countries, especially in the countries of Central and Eastern Europe where innovation management quality improvement is given priority due to the many social, economic and technological changes (Hayo, Seifert 2003; Melnikas, Reichelt 2004; Melnikas 2011, 2013). Considering the many specific characteristics of contempoerary social, economic and technological development and innovation management traditions, the following priorities should be specified in the field of the further improvement and modernization of innovation management specialists development systems:

- implementation of the idea of "life-long integrated university education" into the systems of innovation management specialist development;

- the strengthening of the potential of innovation managers creativity.

"Life-long integrated university education" means that all the tools for specialists development are integrated into one single individualized process of university studies adapted to the development of every concrete specialist. This process has to include all stages of a specialist's development during the career - from obtaining initial qualifica- tion to further qualification improvement. The main stages of this process include the following:

- basic university education with which the person may start their career; this stage includes obtaining traditional university degrees or a specialist's diploma in a certain field;

- introductory training necessary to start a career in a certain field and in a certain position;

- continuous education and continuous training in various forms in order to enhance and refresh specialists' knowledge and develop their new skills relevantly to the changing conditions, working environment and adequately to new requirements: continuous education and continuous training could lead to qualification improvement through in-service training and to obtaining new qualifications through re-training: in the course of continuous education or training every specialist, having chosen any form of individual or group studies in educational centres, institutes or universities, may accumulate a certain set of subjects which will entitle them to a paper certifying their academic, professional or other qualification;

- researches and studies, conducted in diverse forms of long-lasting or periodical character, aimed at resolving problems in the specialist's field of activity and, at the same time, encouraging the specialist's improvement, enhancement of his creative and innovative potential: researche and studies are viewed as a key element of the specialist's professional career and as an important part of the specialist's self-development; involvement in researches and studies is essential in pursuit of an academic qualification, confirmed by scientific degrees and titles;

- involvement in various long-lasting and temporary activities like writing projects, providing consultations, working out strategies and implementing innovations, aimed at resolving problems in the field of the specialist's activity and allowing the specialist to develop his/her administrative skills and practical knowledge.

The idea of a single individualized process of university studies for innovation management specialists development may be realized through various forms. For realization of this idea the potential of local and foreign institutions and organizations should be fully exploited. That means that this process may involve a great number of institutions and organizations; in such cases the organizational and administrative function should be fulfilled by the educational and training centres and institutes directly involved in specialists development. This model of specialists development has some substantial advantages: 
- specialist development is not attached to one specific university or any other educational institution: this allows to develop specialists in multicultural environment taking in view experience of international practice, adopting methods of other countries and creating open, dynamic and innovative development systems;

- it respects needs and career plans of individual specialists;

- individualized educational process is closely linked to solution of the topical practical problems arising in the field of the specialist's activity;

- it ensures wide cooperation of universities, other educational and non-educational institutions and organizations;

- it enables to develop international relations and adopt the experience of international practice;

- it provides application of modern teaching, training and research techniques, including those for distance learning, and use of modern telecommunications and information technologies;

- education, training and scientific research activities are provided and conducted without attachment to one specific university or any other institution and that develops specialists' ability to adjust quickly to a new environment and new requirements.

All the above mentioned advantages prove that the idea of "life-long integrated university studies" has excellent prospects. Therefore it could be assumed that implementation of this idea will facilitate proper operation of innovation management specialists development systems. Additional$l y$, it could be noted that an essential precondition for improvement of innovation management specialists development is creating and enhancing those links which are to ensure and expand interaction between educational systems and systems of professional activities: absence of such links or their inefficient functioning is a serious obstacle for tangible improvement of specialists' development (Armstrong 1999; Steinmueller 2002; Melnikas 2010, 2011).

Interaction of educational systems with systems of professional activities can be enhanced by various means. One of them is establishing and sustaining networks of special organizations with a prospect to integrate into them organizations whose functions include to spread specialists' knowledge and advanced experience, received in the process of the development, across various professional fields.

Interaction of educational systems with systems of professional activities could be defined as an important factor of the strengthening of the po- tential of innovation managers creativity. In general, it could be noted that development of the creative potential of individuals, groups, organizations, different social layers and of all society should be considered an essential precondition for advancement of modern society (Calori et al. 1999; David, Foray 2002; Farnsworth 2005; Perraton 2001; Redding, Venables 2004; Sangmon 2002; Melnikas 2010, 2011, 2013, 2014). The significance of human creativity and creative potential is predetermined by the following factors:

- modern technologies facilitate rapid implementation of the most unexpected and most innovative ideas: it is not the technological capabilities that determine progress and allow to resolve acute problems, but the originality and constructiveness of ideas; that means that people's ability to develop and use properly their creative powers and their ability to generate, appreciate and support new constructive ideas becomes a crucial precondition for successful solution of various economic, social, technical, ecological, political and other problems;

- with growing global competition in various forms priority is more often given to qualitative changes: our creativity and development and exploitation of the creative potential enables us to successfully initiate and implement qualitative changes, adjust to them and, as a result, compete efficiently.

The necessity to develop and fully exploit human creative potential requires more thorough analysis of sources of human creativity and introduction of efficient measures for development, enhancement and better exploitation of the creative potential. That means that development of creativity and creative potential should be viewed as an important field of further scientific research, especially - on improvement of innovation management studies and on the strengthening of the potential of innovation managers creativity..

The problems of human creativity enhancement can be approached from different aspects: as a lack of people's creativity, as an insufficient ability to enhance human creativity, as an insufficient ability to exploit the present creativity potential and insufficient ability to develop it. Understanding of the problems of human creativity enhancement from these aspects allows to determine the most important priorities of the further research on creativity enhancement and the strengthening of the potential of innovation managers creativity. 


\section{Conclusions}

Improvement of innovation managerial human resources, as well as modernization of innovation management studies and, in general, innovation management specialists development systems is a very important direction of modernization of contemporary society, creation of knowledge based society and knowledge economy, activation of the technological advance and the expressing orientation to priorities of intellectualiztion, ability to react to increasingly more rapid changes, tolerance, adaptability and competitiveness under conditions of globalization. It is noteworthy that these priorities are of special importance in the countries of the European Union, especially - in the Central and Eastern Europe, including Lithuania.

Improvement of innovation management studies and innovation management specialists development systems requires systematic approach as well as a whole complex of measures: the measures for the innovation management specialists development improvement have to include all stages of training, academic studies and scientific research activities, also various forms of in-service training, career planning and specialists professional activities in various fields: these measures have to include both individuals' activities and processes of scientific and technological advance as well as processes of social and economic development in different business and public sectors, regions, on the state and international levels.

The following definitions of innovation management studies and of the systems of innovation management specialists development could be described and characterized as most useful and universal:

- innovation management studies - studies, which are focused on the acquisition of theoretical and practical knowledge in innovation activities and innovation management, as well as on the various skills and abilities in the initiation, creation, dissemination and use of innovations, in management and administration of innovation activities;

- the systems of innovation management specialists development - the systems, which unites and combines a various education, training, research, as well as practical activities in the initiation, creation, dissemination and use of innovations, in management and administration of innovations, various activities of life long learning.

Many elements of the synergetic effects search, of integration and synthesis processes should be inherent to the innovation management specialists' professional activities as well as into the systems of innovation management specialists development and into the innovation management studies.

Improvement of innovation management studies and the innovation management specialists development systems modernization in general should be based on diverse principles. These principles include:

- general principles of human resource and specialist development, applicable to specialists of all fields and professions, including that of innovation management;

- specific principles applicable exceptionally to innovation management specialist development;

- exceptional principles of business innovation management specialist development;

- exceptional principles of public innovation management specialist development.

Among especially important principles should be defined the following specific principles of innovation management specialists development:

- the principle of wide erudition and formation of a whole complex of knowledge and skills;

- the principle of coordination of general managerial competence and specific innovation managerial activity;

- the principle of priority of innovativeness and creativity, high morality and high social responsibility;

- the principles of independent decision making, ability to react quickly to changes, taking relevant actions in extreme situations, team-working skills, adaptability to multicultural environment.

The exceptional principles of business innovation management specialists development and public innovation management specialists development highlight special development orientations inherent to various fields of business and public innovation management.

Priority in applying all these principles should be given to establishment and further modernization of innovation management specialists development systems that are based on the implementation of the ideas of integrated individualized academic studies and "life-long learning". These ideas could be viewed as having especially good prospects in the context of the contemporary needs and challenges of strengthening of the potential of innovation managers creativity.

Further theoretical studies, practical works and research on innovation activities, innovation management and on improvement of the systems of innovation management specialist development should be viewed as an essential prerequisite for 
successful encouragement of social and economic advancement. Special attention should be focused on following priorities of scientific research:

- research on new development tyendencies and needs of innovations and innovation activities under contemporary conditions of globalization, the knowledge based society and knowledge economy creation, as well as contemporary challenges of technological advance;

- research on innovation activities and new forms and technologies of innovation management in various business and public sectors;

- research on various aspects of creativity, especially in many specific fields of human creativity enhancement.

\section{References}

Armstrong, M. A. 1999. Handbook of human resource management practice. London: Kogan Page. $922 \mathrm{p}$.

Boldrin, M.; Canova, F. 2001. Inequality and convergence in European regions: reconsidering European regional policies, Economic Policy 16(32): 205.

Calori, R.; Atamer, T.; Nunes, P. 1999. The dynamics of international competition. London: Sage Publications. $256 \mathrm{p}$.

Currie, W. 2000. The global information society. Chichester: John Wiley, 288p.

David, P. A.; Foray, D. 2002. An introduction to the economy of the knowledge society, International Social Science Journal 171: 5-9.

http://dx.doi.org/10.1111/1468-2451.00355

Farnsworth, K. 2005. Promoting business-centred welfare: International and European business perspectives on social policy, Journal of European Social Policy 15(1): 65-80.

http://dx.doi.org/10.1177/0958928705049163

Goeransson, B.; Soederberg, J. 2005. Long waves and information technologies - On the transition towards the information society, Technovation 25(3): 203-211.

http://dx.doi.org/10.1016/S0166-4972(03)00115-9

Grace, A.; Butler, T. 2005. Beyond knowledge management: Introducing learning management systems, Journal of Cases on Information Technology 7(1): $53-70$.

http://dx.doi.org/10.4018/jcit.2005010104

Hayo, B.; Seifert, W. 2003. Subjective economic wellbeing in Eastern Europe, Journal of Economic Psychology 24(3): 329-348. http://dx.doi.org/10.1016/S0167-4870(02)00173-3

Hofbauer, H. 2003. Osterweiterung. Vom Drang nach Osten zur peripheren EU - Integration. Wien: Promedia. 240 p.
Hunt, S. D. 2000. A general theory of competition: resources, competences, productivity. Economic growth. London: Sage Publications. 256 p.

Huseman, R. C.; Godman J. P. 1999. Leading with knowledge: the nature of competition in $21^{\text {st }}$ century. London: Sage Publications. 272 p. http://dx.doi.org/10.4135/9781452220673.n10

Leydesdorff, L. 2004. The university - industry knowledge relationship: Analysing patents and the science base of technologies, Journal of the American Society for Information Science and Technology 55(11): 991-1001. http://dx.doi.org/10.1002/asi.20045

Melnikas, B. 1999. Probleme der Integrattion der baltischen Staaten in westliche Strukturen Berichte des Bundesinstituts fuer ostwissenschaftliche und internationale Studien. N 40, Koeln. 42 p.

Melnikas, B. 2002. Transformacijos. Vilnius: Vaga. 750 p.

Melnikas, B. 2010. "Internationalization and knowledge based society creation process: education and training systems for management specialists, in The $6^{\text {th }}$ International Scientific Conference Business and Management 2010: selected papers, 13 14 May 2010, Vilnius, Lietuva. Vilnius: Technika. ISSN 2029-4441

Melnikas, B. 2011. Transformaciju visuomene: ekonomika, kultūra, inovacijos, internacionalizavimo procesai. Vilnius: Technika.

Melnikas, B. 2013. Žiniomis grindžiamos visuomenès kūrimas: globalizacija, darni plètra, ekonominiai sprendimai. Vilnius: Vilniaus universiteto leidykla. $544 \mathrm{p}$.

Melnikas, B. 2014. Tarptautinis verslas: inovacijos ir žiniu ekonomikos kūrimas: vadovėlis. Vilnius: Technika. 464 p. http://dx.doi.org/10.3846/1484-S

Melnikas, B.; Reichelt, B. 2004. Wirtschaft und Mentalitaet: Tendenzen der EU-Osterweiterung. Leipzig: Leifim - Verlag. 159 p.

Olsen, T. E.; Osmundsen, P. 2003. Spillovers and international competition for investments, Journal of International Economics 59(1): 211-238. http://dx.doi.org/10.1016/S0022-1996(02)00086-7

Perraton, J. 2001. The global economy - myths and realities, Cambridge Journal of Economics 25: 669684. http://dx.doi.org/10.1093/cje/25.5.669

Redding, S.; Venables, A. J. 2004. Economic geography and international inequality, Journal of International Economics 62(1): 53-82. http://dx.doi.org/10.1016/j.jinteco.2003.07.001

Sangmon, K. 2002. A Longitudinal Analysis of Globalization and Rationalization in International Trade: Social Network Approach, Social Forces 81(2): 445-471. http://dx.doi.org/10.1353/sof.2003.0014

Steinmueller, W. E. 2002. Knowledge-based economies and information and communication technologies, International Social Science Journal 54(171): 141-154. http://dx.doi.org/10.1111/1468-2451.00365 